\title{
Feeding value of sorghum stover fed to tropical hair sheep as complete rations in chop, mash, pellet, and block forms
}

\author{
J. Raju1 ${ }^{1 D}$, J. Narasimha ${ }^{1}$, N. Nalini Kumari ${ }^{1}$, T. Raghunanadan ${ }^{1}$, V. Chinni Preetam ${ }^{1}$, A. Ashok Kumar ${ }^{2}$ and \\ P. Ravi Kanth Reddy ${ }^{3}$ id
}

1. Department of Animal Nutrition, PVNR Telangana Veterinary University, Hyderabad, Telangana, India; 2. Department of Plant Breeding, International Crops Research Institute for the Semi-arid Tropics, Hyderabad, Telangana, India;

3. Veterinary Dispensary, Department of Animal Husbandry, Taticherla, Prakasam, Andhra Pradesh, India.

Corresponding author: P. Ravi Kanth Reddy, e-mail: ravi.nutrition001@gmail.com

Co-authors: JR: drrajuj@gmail.com,JN: simha_vet@yahoo.com, NNK: nalini_reddy123@yahoo.co.in, TR: drtrn@rediffmail.com, VCP: dr.preetamvelpula@yahoo.com, AAK: a.ashokkumar@cgiar.org

Received: 30-12-2020, Accepted: 28-07-2021, Published online: 30-08-2021

doi: www.doi.org/10.14202/vetworld.2021.2273-2281 How to cite this article: Raju J, Narasimha J, Kumari NN, Raghunanadan T, Preetam VC, Kumar AA, Reddy PRK (2021) Feeding value of sorghum stover fed to tropical hair sheep as complete rations in chop, mash, pellet, and block forms, Veterinary World, 14(8): 2273-2281.

\begin{abstract}
Background and Aim: Poor palatability, low bulk density, and low nutritive value restrict the utilization of the crop residues as animal feeds. Altering the physical characteristics of feed by blending the roughage and concentrates in the form of complete feed improves the nutrient use efficiency and reduces the feed wastage, feed cost, and labor cost. The study aims to determine suitable processing methods (mash, pellet, or block forms) for efficient utilization of sorghum stover-based complete rations vis-a-vis conventional feeding methods in sheep.
\end{abstract}

Materials and Methods: The sorghum stover was incorporated in complete rations with roughage to concentrate ratio of 50:50 proportion in a growth trial of 120 days. The feed ingredients were chaffed, ground in a hammer mill, passed through expander-extruder, and compressed by feed block machine to prepare chop, mash, pellet, and block form of rations, respectively. Twenty-four male intact growing Nellore $\times$ Deccani cross lambs $(3.5 \pm 0.5$ months age, $14.50 \pm 0.41 \mathrm{~kg}$ (mean \pm SD) at the start of the experiment) were divided into four experimental groups of six animals each in a complete randomized design. The experimental rations were randomly allotted to each group and evaluated for their intake, nutrient utilization, and growth performance.

Results: The sheep fed on pellet-based ration consumed a higher $(\mathrm{p}<0.05)$ quantity of dry matter. The digestibility coefficients of organic matter, crude protein, and neutral detergent fiber were higher $(\mathrm{p}<0.05)$ in processed rations (mash, pellet, or block). Further, the nitrogen balance $(\mathrm{g} / \mathrm{d})$ was higher $(\mathrm{p}<0.05)$ in the mash, pellet, and block form of rations, compared to chopped ration. The processing method did not influence calcium or phosphorous balance parameters, except for their urinary losses, which showed an increasing trend $(\mathrm{p}=0.07)$. The ram lambs fed with pelleted ration showed higher $(\mathrm{p}<0.05)$ weight gain than mash, block, or chaff forms. The efficiency of feed utilization in gaining one kg body weight was higher $(\mathrm{p}<0.05)$ in lambs fed a pelleted diet. Feeding pelletized ration was more economical to gain one $\mathrm{kg}$ body weight. The bulk density was highest for block-based ration followed by pellet, mash, and conventional rations, and the carrying capacity of truck was highest with the least transport cost in block-form of rations.

Conclusion: Physical processing (mash, pellet, and block) of sorghum stover-based complete rations increased the nutrient utilization and growth performance of sheep compared to conventional chopped form. Pelleting the mash with expanderextruder procedure was found to be more profitable. Nevertheless, the cost economics revealed blocks as more preferable forms for transporting the complete rations to larger distances.

Keywords: block, crop residue, digestibility, feed processing, growth, lambs, mash, pellet.

\section{Introduction}

The deficiency of feed and fodder, both in quantitative and qualitative terms, is one of the major constraints in the sustainable development of the livestock sector. Livestock production in developing countries largely depends on fibrous feeds, mainly crop residues [1]. The nutritive value of crop residues

Copyright: Raju, et al. Open Access. This article is distributed under the terms of the Creative Commons Attribution 4.0 International License (http://creativecommons.org/licenses/by/4.0/), which permits unrestricted use, distribution, and reproduction in any medium, provided you give appropriate credit to the original author(s) and the source, provide a link to the Creative Commons license, and indicate if changes were made. The Creative Commons Public Domain Dedication waiver (http://creativecommons.org/ publicdomain/zero/1.0/) applies to the data made available in this article, unless otherwise stated. is low and cannot meet the maintenance requirements on feeding as a sole diet. Poor palatability and low bulk density, along with low nutritive value, restrict the utilization of the crop residues as animal feeds [2]. Blending the roughage and concentrates in the form of complete feed reduces the feed wastage, feed cost, and labor cost apart from improving the nutrient use efficiency [3]. The physical form of complete feed offered as a mash, pellet, or compact feed block significantly impacts nutrient intake. The altered physical characteristics of feed may regulate ruminal fermentation process toward reduced methanogenesis with concomitant energy saving, higher metabolizable energy (ME) intake, and improved microbial protein 
synthesis [4]. The physical form of the ration can also affect the potential rate of consumption with pelletized rations ingested more rapidly than the mash forms [5]. Feeding the ruminants with complete feed stabilized rumen fermentation, minimized selective feeding and fermentation losses, and ensured better ammonia utilization in the rumen [6].

Pelletizing is an efficient technique in improving the intake, digestibility, feed conversion, and growth performance of livestock [7]. The heat, moisture, and mechanical pressure applied during conditioning and pelleting cause certain physical and chemical alterations having beneficial or detrimental effects on feed components, gastrointestinal development, and growth performance [8]. Besides, the application of heat and pressure during pelleting promotes starch gelatinization [9]. Pelleted meal reduces the particle size and increases the available surface for microbial degradation and substrate fermentation [10]. Further, pelleting causes a more gradual release of oil in the rumen and a higher rumen escape of dietary crude protein $(\mathrm{CP})$, thereby increasing the bioavailability of dietary protein [11]. Providing complete feed in block form positively affects feed protein digestibility and energy utilization, which can be used for production while reducing the feed cost and environmental burden [4].

In India, agricultural residues are mostly burnt in the field after harvest, releasing pollutants at a large extent [12]. The low digestibility of crop residues, such as sorghum stover, is one of the main reasons for denying its usage as feed. Although the nutritive value of stover could be increased by chopping, a conventional form of feeding, its usage as a roughage source is not being encouraged in surplus fodder available areas. The favorable effects of processing crop residue-based rations against conventional chopped forms have to be explored in detail $[13,14]$.

The study aims to determine suitable processing methods (mash, pellet, or block forms) for efficient utilization of sorghum stover-based complete rations vis-a-vis conventional feeding methods in sheep.

\section{Materials and Methods}

\section{Ethical approval}

Animal handling techniques and experimental protocols followed in the present study were approved by the Committee for the Purpose of Control and Supervision of Experiments on Animals (approval number SA-201715), P.V. Narsimha Rao Telangana Veterinary University, Hyderabad, India.

\section{Study period and location}

The study was conducted from November 2016 to April 2017. The in vivo experiment was carried out at the college of veterinary science, P. V. Narsimha Rao Telangana Veterinary University, Hyderabad, India $\left(17^{\circ} 12 \mathrm{~N}, 78^{\circ} 18 \mathrm{E}, 545 \mathrm{~m}\right.$ above sea level). The ambient temperature and relative humidity values during the study period were in the range of $28-42^{\circ} \mathrm{C}$ and $28-32 \%$, respectively.

\section{Experimental rations}

Experimental rations with roughage (sorghum stover) to concentrate ratio of 50:50 were formulated and the rations were processed into either mash, expander extruder pellet, or block form. The control diet comprised a conventional ration prepared by mixing chaffed sorghum stover with concentrate mixture at 50:50 proportion. The prepared rations were evaluated for performance, nutrient digestibilities, and nitrogen, calcium, and phosphorus balance in Nellore $\times$ Deccani cross ram lambs. Before starting the trial, a complete ration was processed to mash form. Then one-third of the mash was subjected to expander extruder pelleting and another one-third to compact feed block making.

\section{Chopping}

The sorghum stover was chopped to 1.5-2.0 $\mathrm{cm}$-sized pieces using a chaff cutter (Niharika Agro Mech Industries, India). The chopped stover pieces were mixed with ground concentrate ingredients at 50:50 proportion.

\section{Preparation of mash}

The experimental feed ingredients were ground in a hammer mill (Niharika Agro Mech Industries, India) using an 8-mm sieve. The ground material, mineral mixture, and vitamin premix were mixed for $10 \mathrm{~min}$ in a horizontal mixer. Molasses was heated to $70^{\circ} \mathrm{C}$ in the preheating chamber and added into the mixer directly while mixing.

\section{Expander-extruder processing}

The mash of complete ration was reconstituted by adding water to obtain $17-18 \%$ moisture. The material is then passed through a screw in the barrel of the expander-extruder (Niharika Agro Mech Industries, India) to attain $90-95^{\circ} \mathrm{C}$ by the time the pellet passes the die openings with a diameter of $16 \mathrm{~mm}$. The obtained pellets were later cooled and collected into bags.

\section{Complete feed block making}

Complete feed blocks were prepared by compressing the mash form of ration at $5000 \mathrm{psi}$ $\left(351.9 \mathrm{~kg} / \mathrm{cm}^{2}\right)$ using an electrically operated animal feed block making machine (Niharika Agro Mech Industries, India).

\section{Experimental animals and feeding}

Twenty-four male intact growing Nellore $\times$ Deccani cross lambs $(3.5 \pm 0.5$ months age, $14.50 \pm 0.41 \mathrm{~kg}$ ) were divided into four experimental groups of six animals each in a complete randomized design. The experimental rations were randomly allotted to each group and evaluated for their intake, nutrient utilization, and growth performance. The experimental ram lambs were housed in individual pens $(4 \mathrm{~m} \times 3 \mathrm{~m})$ with free water access. All the animals were de-wormed and vaccinated against Peste des Petits Ruminants disease at the beginning of the experiment. The three processed sorghum stover-based complete rations were evaluated through a 
growth trial for 120 days and compared with the conventional control ration. The ingredient and chemical composition $(\mathrm{g} / \mathrm{kg})$ of experimental complete rations are shown in Table-1.

Animals were offered with experimental feeds ad libitum twice daily at 9:00 $\mathrm{h}$ and 15:00 h. Feed offered and orts, if any, were weighed daily to record feed intake. The feeding trial was carried out for 141 days duration, including the first 21 days for adaptation and subsequent 120 days for measurement of growth trial. The amount of ration was adjusted weekly as per each animal's body weight changes to meet the nutrient requirement [15]. The experimental animals were weighed weekly before offering feed and water in the morning. Weights were recorded for two consecutive days and the body weights were represented as their mean values.

\section{Metabolism study}

Metabolism trial was conducted after 90 days of feeding. Sheep were kept in well-ventilated individual metabolism cages $(90 \mathrm{~cm} \times 75 \mathrm{~cm} \times 90 \mathrm{~cm})$ to ensure feces and urine and were collected separately. Animals were allowed for a 5-day acclimatization period followed by 7 days of collection. The amounts of feed offered and refusal, feces, and urine voided per animal were weighed daily during the collection period. Feces and urine from each animal were collected

Table-1: Ingredient and chemical composition ( $\left.\mathrm{g} \mathrm{kg}^{-1}\right)$ of differently processed sorghum stover based complete rations for growth study in lambs.

\begin{tabular}{lcccc}
\hline Component & Control & Mash & Pellet & Block \\
\hline Ingredient composition & & & & \\
Sorghum stover & 500 & 500 & 500 & 500 \\
Maize & 100 & 100 & 100 & 100 \\
Cotton seed cake & 80 & 80 & 80 & 80 \\
Ground nut cake & 40 & 40 & 40 & 40 \\
De-oiled rice bran & 160 & 160 & 160 & 160 \\
Red gram chuni & 50 & 50 & 50 & 50 \\
Molasses & 50 & 50 & 50 & 50 \\
Urea & 5 & 5 & 5 & 5 \\
Mineral mixture* & 10 & 10 & 10 & 10 \\
Salt & 5 & 5 & 5 & 5 \\
Chemical composition & & & & \\
OM & 905 & 902 & 902 & 903 \\
CP & 118 & 119 & 120 & 120 \\
EE & 29 & 28 & 27 & 27 \\
TCHO & 757 & 755 & 754 & 756 \\
NDF & 541 & 539 & 531 & 530 \\
ADF & 369 & 367 & 360 & 362 \\
Cellulose & 262 & 261 & 255 & 260 \\
Hemi cellulose & 172 & 172 & 171 & 168 \\
Ash & 95.2 & 97.9 & 98.6 & 96.8 \\
Lignin & 42.3 & 41.5 & 42.1 & 41.0 \\
Ca & 11.2 & 10.8 & 10.9 & 10.7 \\
P & 6.3 & 6 & 6.3 & 5.9 \\
\hline
\end{tabular}

$\mathrm{OM}=$ Organic matter, $\mathrm{CP}=$ Crude protein, $\mathrm{EE}=$ Ether extract, $\mathrm{TCHO}=$ Total carbohydrates, NDF $=$ Neutral detergent fiber, $A D F=A c i d$ detergent fiber; $\mathrm{Ca}=\mathrm{Calcium}$, $\mathrm{P}=$ Phosphorus. *Mineral mixture $1 \mathrm{~kg}$ contains $\mathrm{Cu}-2 \mathrm{~g}$, Co-100 mg, Fe-6 g, Zn-2.2 g, Ca-220g, P-100g,

$\mathrm{Mg}-40 \mathrm{~g}$, Co-100 mg, Iodine-200 mg, $\mathrm{B}_{1}-1300 \mathrm{mg}$, $B_{6}-130 \mathrm{mg}, B_{12}-3000 \mathrm{mg}$, Vit E-975 IU, Vit A-750000 IU, Vit $D_{3}-150000$ IU daily and pooled in iron and glass containers, respectively. A representative sample of daily feed offered and refusal from individual animals was collected and pooled. After estimating dry matter (DM), the samples of all the experimental feeds, refusals, and feces were ground separately in a laboratory Willey mill through $1 \mathrm{~mm}$ screen and preserved in self-sealed covers. A sub-sample of feces $\left(1 / 10^{\text {th }}\right)$ and urine $\left(1 / 5^{\text {th }}\right)$ was acidified using $10 \%(\mathrm{w} / \mathrm{w}) \mathrm{H}_{2} \mathrm{SO}_{4}$ to prevent nitrogen loss and then stored at $-20^{\circ} \mathrm{C}$ to estimate nitrogen, calcium, and phosphorus.

\section{Feed analysis}

The chemical analysis of experimental feed, residues, and feces was carried out following the methods of AOAC (2000) [16]. DM was determined by the oven drying method (934.01), CP by Kjeldahl method (VAPODEST 200, Germany) (984.13) (N×6.25), ash by muffle furnace incineration (942.05), and ether extract (EE) by Soxtherm method (SOX 406/416, Germany) (920.39). Organic matter (OM) and total carbohydrate (TCHO) were calculated by differences. The fiber components (neutral detergent fiber, [NDF]; acid detergent fiber, $[\mathrm{ADF}]$ ) were analyzed and expressed inclusive of residual ash by the methods of Van Soest et al. [17]. Sodium sulfite and heat-stable $\alpha$-amylase were not used in the determination of NDF. Calcium $(\mathrm{Ca})$ and total inorganic phosphorus $(\mathrm{P})$ in feed, feces, and urine were also estimated [16]. The density of chopped sorghum stover, concentrate mixture, and mash and pellet forms of complete rations were measured using the cubic boxes of known dimensions, while the density of block forms was calculated by measuring its weight and dimensions.

\section{Cost economics}

The cost of feed and cost of feed $/ \mathrm{kg}$ body weight gain were calculated by analyzing the body weight gain and total feed intake for the entire trial. Prevailing market prices of India (Hyderabad, Telangana) were taken into account to calculate the cost of individual ingredients of concentrate mixture and $\mathrm{kg}$ live weight.

\section{Statistical analysis}

The results obtained were subjected to statistical analysis and tested for significance as per Duncan's multiple range test using a general linear model. The model includes individual animals as a random effect, treatment as a fixed effect, experimental error, and initial BW as a covariate. The results were presented as means with standard errors. The means were considered significant at $\mathrm{p}<0.05$ and the differences among means were determined by marking Tukey's test. The entire statistical analysis was conducted using Statistical Package for the Social Sciences version 23.0 (IBM Corp., New York, USA).

\section{Results}

\section{Chemical composition}

The ingredient and chemical composition of differently processed complete rations are presented in 
Table-1. The differences in nutrient composition of the various physical forms were insignificant. The $\mathrm{CP}$, $\mathrm{NDF}$, and ADF values (g/kg DM) ranged from 118 to 120,530 to 541 , and 360 to 369 , respectively.

\section{DM intake (DMI) and nutrient digestibility}

The types of physical processing affected DMIs with the highest $(\mathrm{p}<0.05) \mathrm{DM}$ consumption in the lambs fed expander-extruded pellet form of ration (Table-2). Processing of the conventional feed through mashing, pelletizing, and block making increased $(p<0.05)$ digestibility coefficients of $\mathrm{OM}, \mathrm{CP}$, and NDF; however, no differences were observed among the different processing methods (Table-2). Further, the DM and cellulose digestibilities were tended to be higher in lambs fed processed rations. The physical processing did not affect intakes of nutrients, on per kg metabolic body weight basis, except for OM, total digestible nutrients (TDN), and ME, who tended to increase in the lambs fed mash, pellet, or block forms. The nutritive values in terms of digestible CP $(\mathrm{DCP}), \mathrm{TDN}$, and ME were higher $(\mathrm{p}<0.05)$ for mash, pellet, and block form of rations compared to conventional rations containing chopped stover mixed with ground concentrate ingredients.

\section{Nitrogen, calcium, and phosphorus balance}

All the lambs of the trial were in positive nitrogen, calcium, and phosphorus balance (Table-3). Although the fecal and urinary losses of nitrogen were not affected by processing, the intake, balance, and retained nitrogen levels were higher in the lambs fed

Table-2: Effect of differently processed sorghum stover-based complete rations on intake and nutrient digestibility in lambs.

\begin{tabular}{|c|c|c|c|c|c|c|}
\hline Parameter & Control & Mash & Pellet & Block & SEM & p-value \\
\hline \multicolumn{7}{|c|}{ Nutrient digestibility $\left(\mathrm{g} \mathrm{kg}^{-1}\right)$} \\
\hline DM & 597 & 613 & 637 & 613 & 6.6 & 0.07 \\
\hline OM & $605^{a}$ & $641^{\mathrm{b}}$ & $643^{\mathrm{b}}$ & $631^{b}$ & 8.5 & 0.05 \\
\hline $\mathrm{CP}$ & $642^{a}$ & $687^{b}$ & $707^{b}$ & $682^{\mathrm{b}}$ & 8.7 & 0.03 \\
\hline $\mathrm{EE}$ & 777 & 788 & 790 & 782 & 3.8 & 0.66 \\
\hline $\mathrm{TCHO}$ & 570 & 607 & 607 & 596 & 9.5 & 0.11 \\
\hline NDF & $559^{a}$ & $583^{b}$ & $599^{b}$ & $589^{b}$ & 5.5 & 0.04 \\
\hline ADF & 506 & 516 & 532 & 522 & 6.3 & 0.12 \\
\hline Cellulose & 503 & 512 & 527 & 515 & 7.3 & 0.06 \\
\hline $\begin{array}{l}\text { Hemi } \\
\text { cellulose }\end{array}$ & 673 & 706 & 726 & 711 & 13.2 & 0.12 \\
\hline \multicolumn{7}{|c|}{ Nutrient intake $\left(\mathrm{g} \mathrm{d}^{-1} \mathrm{~kg}^{-1} \mathrm{~W}^{0.75}\right)$} \\
\hline DM & 88.74 & 92.1 & 96.04 & 93.35 & 1.65 & 0.12 \\
\hline OM & 80.27 & 83.09 & 86.59 & 84.28 & 1.3 & 0.06 \\
\hline DCP & 6.75 & 7.56 & 8.17 & 7.64 & 0.22 & 0.10 \\
\hline TDN & 49.61 & 54.56 & 57.13 & 54.59 & 1.3 & 0.09 \\
\hline $\begin{array}{l}\text { ME (MJ } \\
\left.\mathrm{kg}^{-1} \mathrm{~W}^{0.75}\right)\end{array}$ & 0.75 & 0.83 & 0.86 & 0.83 & 0.07 & 0.07 \\
\hline \multicolumn{7}{|c|}{ Nutritive value ( $\left.\mathrm{g} \mathrm{kg}^{-1} \mathrm{DM}\right)$} \\
\hline DCP & $76^{a}$ & $82^{\mathrm{b}}$ & $85^{b}$ & $82^{b}$ & 1.2 & 0.03 \\
\hline TDN & $559^{a}$ & $592^{b}$ & $595^{b}$ & $584^{b}$ & 7.4 & 0.05 \\
\hline $\operatorname{ME}(\mathrm{MJ} / \mathrm{kg})$ & $8.45^{\mathrm{a}}$ & $8.96^{b}$ & $9.01^{b}$ & $8.83^{b}$ & 0.26 & 0.04 \\
\hline \multicolumn{7}{|c|}{$\begin{array}{l}{ }^{a b c} \text { values bearing different superscripts in a row differ } \\
\text { significantly }(p<0.05)(n=6) \text {. OM=Organic matter, } \\
C P=\text { Crude protein, } E E=\text { Ether extract, TCHO=Total } \\
\text { carbohydrates, NDF=Neutral detergent fiber, } A D F=\text { Acid } \\
\text { detergent fiber, TDN=Total digestible nutrients, } \\
\text { ME=Metabolizable energy, DCP=Digestible crude protein }\end{array}$} \\
\hline
\end{tabular}

on processed rations. However, the type of processing did not affect any of the calcium and phosphorus attributes, except for urinary losses, which tended to increase $(p=0.07)$ in processed rations. The calcium and phosphorus intake and retention were comparable among all the rations.

\section{Growth performance}

Processing complete rations into different physical forms did not influence the weekly body weight changes of lambs during 120 days of feeding (Figure-1). However, the weekly DMIs were higher in pellet rations followed by block, mash, and conventional rations, respectively (Figure-2). The weight gain of ram lambs fed expander extruded pellet form of complete ration was higher $(\mathrm{p}<0.01)$ than conventional, mash, and block form of rations (Table-4). Feeding processed rations improved $(\mathrm{p}<0.05)$ the average daily gain (ADG) of lambs. Among the processed rations, pelletized rations revealed higher ADG compared to the other two processing forms. The lambs fed pelletized rations efficiently $(\mathrm{p}<0.05)$ utilized the feed to gain $1 \mathrm{~kg}$ body weight.

\section{Cost economics}

The cost economics analysis of feeding differently processed rations is presented in Table-5. Cost $(\$)$ of feed per $\mathrm{kg}$ gain was lower $(\mathrm{p}<0.05)$ in a pelleted ration. The cost of feed $(\$)$ per $\mathrm{kg}$ gain was $1.98,2.01,1.78$, and 1.94 for conventional, mash, pellet, and block forms of rations, respectively. As

Table-3: Effect of feeding differently processed sorghum stover-based complete rations on nitrogen, calcium, and phosphorus balance $\left(\mathrm{g} \mathrm{d}^{-1}\right)$ in lambs.

\begin{tabular}{|c|c|c|c|c|c|c|}
\hline Attribute & Control & Mash & Pellet & Block & SEM & p-value \\
\hline \multicolumn{7}{|l|}{ Nitrogen } \\
\hline Intake & $16.92^{a}$ & $17.89^{a}$ & $19.87^{b}$ & $18.51^{\mathrm{b}}$ & 0.83 & 0.05 \\
\hline Fecal loss & 6.89 & 6.54 & 6.65 & 6.7 & 0.27 & 0.96 \\
\hline $\begin{array}{l}\text { Urinary } \\
\text { loss }\end{array}$ & 5.19 & 5.77 & 6.23 & 5.7 & 0.34 & 0.25 \\
\hline Balance & $4.84^{a}$ & $5.58^{\mathrm{b}}$ & $6.99^{b}$ & $6.12^{b}$ & 0.45 & 0.04 \\
\hline $\begin{array}{l}\text { Retention } \\
\text { (\% intake) }\end{array}$ & $28.61^{a}$ & $31.19^{\mathrm{b}}$ & $35.18^{\mathrm{b}}$ & $33.17^{b}$ & 1.22 & 0.05 \\
\hline $\begin{array}{l}\text { Retention } \\
\text { (\% } \\
\text { absorbed) }\end{array}$ & $41.26^{\mathrm{a}}$ & $46.04^{b}$ & $51.25^{\mathrm{b}}$ & $47.78^{b}$ & 1.58 & 0.05 \\
\hline \multicolumn{7}{|l|}{ Calcium } \\
\hline Intake & 9.99 & 10.13 & 11.22 & 10.27 & 0.45 & 0.34 \\
\hline Fecal loss & 4.75 & 5.43 & 4.87 & 5.12 & 0.22 & 0.45 \\
\hline $\begin{array}{l}\text { Urinary } \\
\text { loss }\end{array}$ & 1.87 & 1.57 & 2.67 & 1.73 & 0.17 & 0.07 \\
\hline Balance & 3.37 & 3.13 & 3.68 & 3.42 & 0.22 & 0.78 \\
\hline $\begin{array}{l}\text { Retention } \\
\text { (\% intake) }\end{array}$ & 33.72 & 30.87 & 32.81 & 33.29 & 0.98 & 0.97 \\
\hline \multicolumn{7}{|l|}{ Phosphorus } \\
\hline Intake & 5.62 & 5.63 & 6.49 & 5.66 & 0.27 & 0.22 \\
\hline Fecal loss & 1.81 & 1.69 & 1.92 & 1.78 & 0.15 & 0.64 \\
\hline $\begin{array}{l}\text { Urinary } \\
\text { loss }\end{array}$ & 2.67 & 2.7 & 3.12 & 2.64 & 0.19 & 0.07 \\
\hline Balance & 1.14 & 1.24 & 1.45 & 1.24 & 0.09 & 0.33 \\
\hline $\begin{array}{l}\text { Retention } \\
\text { (\% intake) }\end{array}$ & 20.26 & 21.96 & 22.29 & 21.93 & 1.56 & 0.74 \\
\hline
\end{tabular}




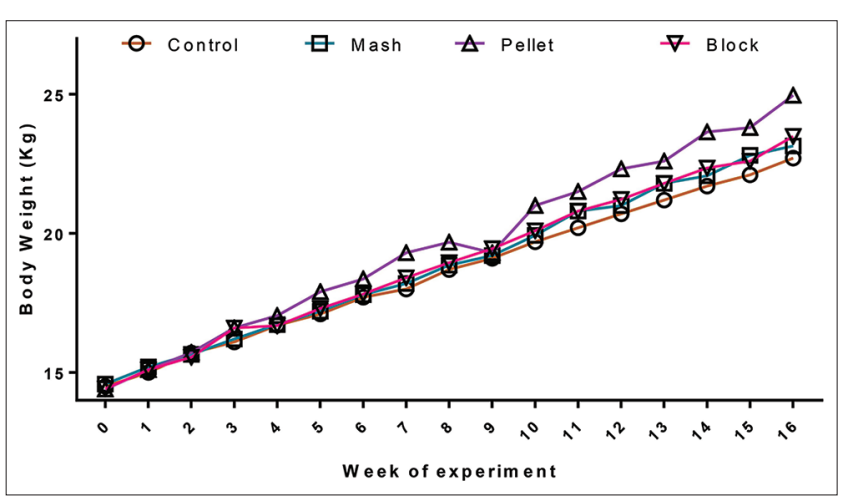

Figure-1: Body weights $(\mathrm{kg})$ of the lambs-fed chopped, mash, pellet, and block form of rations during the growth trial.

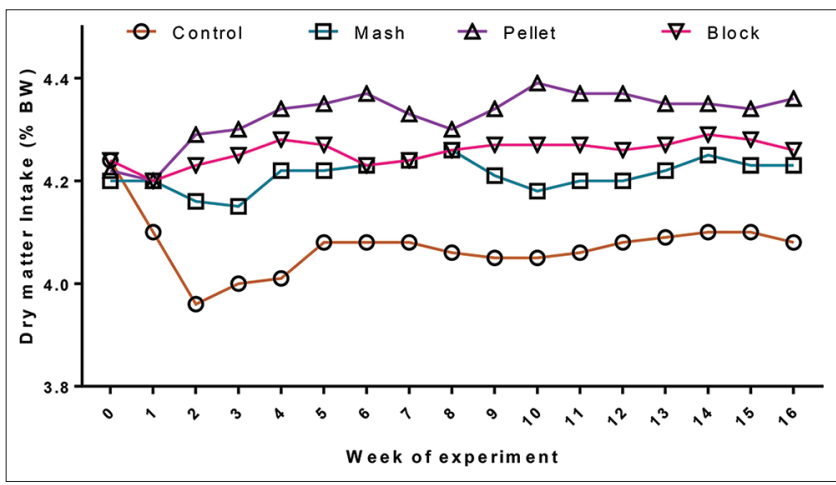

Figure-2: Dry matter intakes (\%body weight) of the lambs-fed chopped, mash, pellet, and block form of rations during the growth trial.

anticipated, the bulk density was highest for block form of ration followed by pellet, mash, and conventional rations. Further, the carrying capacity of truck was highest with the least transport cost in block-form of rations. The combined cost of both processing and transport was highest in conventional rations than in the differently processed rations.

\section{Discussion}

\section{Chemical composition}

Processing did not affect the chemical composition of the experimental rations, presumably due to similar ingredient composition and roughage to concentrate ratio $[18,19]$. Likewise, few researchers reported unaltered chemical composition on processing the rations through different processing methods such as chaffing, grinding, and expander extruder pelleting [5,20]. However, Anandan et al. [21] reported lower $(\mathrm{p}<0.05) \mathrm{CP}$ and NDF contents in block form of sweet sorghum bagasse-based complete rations compared to mash and pellets forms. In another study, Anandan et al. [13] reported higher ADF and acid detergent lignin values in block form of maize stover-based complete rations than mash form, despite having similar ingredients and proportions. However, the authors did not provide explanations for the alterations in the chemical composition according to the type of processing method.
Table-4: Effect of feeding differently processed sorghum stover-based complete rations on growth rate and feed intake in lambs.

\begin{tabular}{|c|c|c|c|c|c|c|}
\hline \multirow{2}{*}{\multicolumn{3}{|c|}{$\begin{array}{l}\text { Parameter Control Mas } \\
\text { Body weight changes }(\mathrm{kg})\end{array}$}} & \multirow{2}{*}{ Pellet } & \multirow[t]{2}{*}{ Block } & \multirow[t]{2}{*}{ SEM } & \multirow[t]{2}{*}{ p-value } \\
\hline & & & & & & \\
\hline Initial BW & 14.50 & 14.58 & 14.40 & 14.42 & 0.41 & 0.89 \\
\hline Final BW & 22.70 & 23.14 & 24.96 & 23.49 & 0.30 & 0.12 \\
\hline $\begin{array}{l}\text { Total BW } \\
\text { gain }\end{array}$ & $8.20^{\mathrm{a}}$ & $8.56^{a b}$ & $10.56^{c}$ & $9.07^{b}$ & 0.38 & 0.05 \\
\hline $\begin{array}{l}\text { Average } \\
\text { daily gain } \\
\left(\mathrm{g} \mathrm{d}^{-1}\right)\end{array}$ & $68.33^{a}$ & $71.33^{b}$ & $88.09^{d}$ & $75.58^{c}$ & 2.16 & 0.05 \\
\hline \multicolumn{7}{|l|}{ DM intake } \\
\hline $\begin{array}{l}\text { DM intake } \\
\left(\mathrm{g} \mathrm{d}^{-1}\right)\end{array}$ & $892.6^{a}$ & $936.7^{b}$ & $1030.2^{\circ}$ & $960.3^{b}$ & 13.24 & 0.05 \\
\hline $\begin{array}{l}\text { DM intake } \\
\left(\mathrm{g} / \mathrm{kg}^{0.75}\right)\end{array}$ & $88.74^{a}$ & $92.10^{\mathrm{b}}$ & $96.04^{c}$ & $93.35^{b}$ & 1.65 & 0.05 \\
\hline $\begin{array}{l}\text { FCR }(\mathrm{kg} \\
\text { feed/kg } \\
\text { gain) }\end{array}$ & $11.07^{b}$ & $11.15^{b}$ & $9.72 a$ & $10.69^{b}$ & 0.63 & 0.05 \\
\hline $\begin{array}{l}\text { Cost of } \\
\text { feed/kg } \\
\text { (USD) }\end{array}$ & 0.179 & 0.180 & 0.183 & 0.181 & - & - \\
\hline $\begin{array}{l}\text { Cost of } \\
\text { feed/ } \\
\text { kg gain } \\
\text { (USD) }\end{array}$ & $1.98^{b}$ & $2.01^{b}$ & $1.78^{\mathrm{a}}$ & $1.94^{\mathrm{b}}$ & 0.11 & 0.05 \\
\hline
\end{tabular}

${ }^{a b c}$ values bearing different superscripts in a row differ significantly $(p<0.05)(n=6)$. USD=U.S. Dollar, BW=Body weight gain, $\mathrm{DM}=$ Dry matter, $\mathrm{FCR}=$ Feed conversion ratio

Table-5: Effect of processing on feed transport and cost economics.

\begin{tabular}{|c|c|c|c|c|c|c|}
\hline Parameter & Control & I Mash & Pellet & Block & SEM & p-value \\
\hline \multicolumn{7}{|l|}{ Feed cost } \\
\hline $\begin{array}{l}\text { Cost of } \\
\text { feed/ton } \\
\text { (USD) }\end{array}$ & 184.8 & 186.2 & 189.0 & 187.6 & - & - \\
\hline $\begin{array}{l}\text { Cost of } \\
\text { feed/ } \\
\text { kg gain } \\
\text { (USD) }\end{array}$ & $2.05^{b}$ & $2.08^{b}$ & $1.84^{c}$ & $2.01^{c}$ & 0.09 & 0.05 \\
\hline \multicolumn{7}{|c|}{ Transport cost and economics } \\
\hline $\begin{array}{l}\text { Bulk } \\
\text { density } \\
\left(\mathrm{kg} / \mathrm{m}^{3}\right)\end{array}$ & $147^{a}$ & $323^{b}$ & $442^{c}$ & $529 d$ & 26.62 & 0.04 \\
\hline $\begin{array}{l}\text { Processing } \\
\text { cost } \\
\text { (USD/ton) }\end{array}$ & 6.45 & 7.75 & 9.68 & 8.39 & - & - \\
\hline $\begin{array}{l}\text { Carrying } \\
\text { capacity/ } \\
\text { truck } \\
\text { (tons) }\end{array}$ & 6.66 & 14.64 & 20.02 & 23.98 & - & - \\
\hline $\begin{array}{l}\text { Transport } \\
\text { cost } \\
\text { (USD/ton/ } \\
100 \mathrm{~km})^{\mathrm{b}}\end{array}$ & 9.73 & 4.43 & 3.24 & 2.70 & - & - \\
\hline $\begin{array}{l}\text { Processing } \\
+ \\
\text { transport } \\
\text { cost } \\
\text { (USD/ } \\
\text { ton/100 } \\
\mathrm{km} \text { ) }\end{array}$ & 16.63 & 12.71 & 14.27 & 12.36 & - & - \\
\hline
\end{tabular}

${ }^{a} 1600$ cubic feet carrying capacity. ${ }^{b}$ Assuming a fuel efficiency of $4 \mathrm{~km} / \mathrm{L}$ and cost of diesel $0.89 \mathrm{USD} / \mathrm{I}$. USD $=$ U.S. Dollar 


\section{DMI, nutrient digestibility, and nutritive value}

The higher DMI of pellet form of ration compared to other physical forms may be attributed to the increased palatability and acceptability of the pelleted ration. The DMI was similar in mash and block forms but higher $(\mathrm{p}<0.05)$ than the conventional ration. Processing decreases the particle size and collapses the cell wall structure, thereby increasing the density and hydration of feed. Compressing feed during block-making process reduces its volume and increases the bulk density [22]. The greater density will allow a faster passage rate and less rumen volume, consequently increasing the voluntary DMI [23]. Besides, the lower DMI of conventional ration might be due to the poor palatability of chaffed sweet sorghum and facilitated choice of selecting roughage and concentrate separately [3]. Similar findings on feeding bajra straw-based ration were reported elsewhere [24,25]. In a study, Anandan et al. [21] reported higher DMI in sheep fed mash and pellet form of sweet sorghum bagasse-based complete rations compared to those fed chops or block forms [21]. Further, Khan et al. [18] observed 20-29\% higher DMI in lambs fed mash form than block form of complete ration. They attributed the lower DMI in block form to the temporal segregation of concentrate and roughage in block due to the larger particle size of chop form of roughage $(2-3 \mathrm{~cm})$, causing refusal of unpalatable portions of stover/straw. However, our study used ground form of roughage $(8 \mathrm{~mm})$, resulting in similar DMI of mash and block forms of rations in sheep. Higher voluntary feed intake in processed rations (mash, pellet, and block) might be explained by the avoidance of refusing unpalatable portions of roughage due to the decreased particle size. Besides, lesser retention time due to the higher rate of passage of the smaller feed particles in the mash could have favored intake to some extent at the expense of reduced digestibility [26].

The findings of this study indicate a higher intake of mash form than those fed block form of ration, leading to the higher passage rate of digesta and lower digestibility of earlier form. The digestibilities of OM, $\mathrm{CP}$, and NDF were comparable between the processed rations but higher than the conventional ration. The physical form of the rations did not influence the digestibility coefficients of DM, EE, TCHO, ADF, cellulose, and hemicellulose. Likewise, Nalini Kumari et al. reported higher digestibilities of OM and CP in sweet sorghum bagasse-based extruded pellet form of ration than mash and chop forms in sheep [20]. Singh et al. [27] observed similar digestibility coefficients of DM, OM, and CP between the mash and block form of complete feed in calves. Meanwhile, Khan et al. [18] reported no effect of physical form on the digestibilities of nutrients, except for CP digestibility, which was lower $(\mathrm{p}<0.05)$ in mash form than the block form ration.

Blending, heat processing, and densification practices followed while processing might have improved the digestibilities of OM, CP, and NDF contents. Thermal processing modifies the nutritional profile through several mechanisms and provides beneficial effects on the host [28]. Heat processing causes starch gelatinization and exposes the crystalline or physically inaccessible starches (resistant starch entrapped in a cellular matrix) to enzymatic or microbial digestion [9]. The beneficial effects of pelletizing the crop residue-based complete rations on CP digestibility are well evident $[29,30]$. Heat processing contributes to higher microbial protein yield by increasing the ruminal fermentable starch causing efficient utilization of available nitrogen [31]. The expander-extruder processing causes a Maillard reaction, forming cross-linkages between peptide chains and carbohydrates, promoting the bypass protein into small intestine [32]. Moreover, shear force by expander would unleash the bound nutrients and increase their accessibility by rumen microbes or enzymes [33]. In the current study, the energy content of rations was sufficient for synchronization with the available nitrogen while synthesizing the microbial protein [34].

Type of physical processing (mash or pellet or block) did not affect the nutrient digestibilities. However, Anandan et al. [21] reported the lower OM digestibility $(\mathrm{p}<0.05)$ in pellet and mash form of rations as compared to the block and chop forms in sheep fed sweet sorghum bagasse-based rations. Another Iranian study found higher digestibilities of DM, CP, NDF, and ADF in sheep fed complete feed block compared to mash and pellet form of rations. These results are justified by higher $(\mathrm{p}<0.01)$ rumen protozoal population (total protozoa, Entodinium spp., and Epidinium spp.) in sheep fed on block form of ration compared to mash and pellet forms [5].

Processing of complete rations increased $(\mathrm{p}<0.05)$ the DCP, TDN, and ME contents. The DCP and TDN intakes were comparable to the values given by Dhuria et al. [25] in sheep fed gram straw-based complete feed in loose or block forms. The lower $(p<0.01)$ DCP content in chop form of ration was the reflection of lower CP digestibility. In corroboration, Kumari [35] reported higher $(\mathrm{p}<0.01)$ DCP, TDN, and ME contents of sweet sorghum bagasse based pelleted ration compared to mash and chop form of rations fed to sheep. Reddy et al. [36] also observed higher DCP and TDN content of expander extruded complete ration with $40 \%$ sugarcane bagasse in buffalo bulls and Ongole bull calves. However, Singh et al. [27] observed that the DCP and TDN intake did not differ among calves fed either block or mash form of rations. The average daily DM, DCP, TDN, and ME intakes of lambs in the experiment were higher than the nutrient requirements at $20 \mathrm{~kg}$ body weight, growing at $75 \mathrm{~g}$ of ADG [15]. The differences in intake and digestibility of nutrients among various physical forms reflected the plane of nutrition. 


\section{Nitrogen, calcium, and phosphorus balance}

Processing increased the intake, balance, and retention of nitrogen. The higher nitrogen retention might have been attributed to the higher CP digestibility and intake of differently processed rations. Another advantage is the improved utilization of absorbed nitrogen by matching the supply of energy in the form of fermentable carbohydrates. Similarly, Reddy et al. [37] revealed that nitrogen balance was higher by $48 \%$ in lambs fed different fibrous agricultural residue-based complete rations processed into mash form. The differences in nitrogen retentions among the processed forms (mash, pellet, and block) are barely distinguishable. However, few authors reported higher nitrogen retention on feeding the rations processed into expander extruded pellet form compared to mash and chop forms [20,38]. Further, Khan et al. [18] observed higher nitrogen intake and balance in sheep fed complete rations in mash form compared to the block form.

None of the calcium and phosphorus balance-related parameters was affected by processing the rations. The calcium and phosphorus balance in herbivorous animals could be directly related to their levels in feed consumed [39]. Although not significant, a trend of higher urinary losses of calcium and phosphorus was observed in pelleted rations, probably due to the higher levels of the respective minerals in pelleted form of ration [40]. Similar to present findings, no significant effect on calcium retention was observed in calves and buffalo bulls fed sugarcane bagasse-based expander extruded pellet compared to conventional ration $[41,42]$.

\section{Growth performance}

The weight gain and ADG were higher in pellet-fed groups compared to conventional, mash, and block form of rations. Our findings appear to be substantiated by Reddy et al. [43] andAnandan et al. [21], who reported that pelleting improved daily weight gain in lambs and kids compared to chop, mash, or block form of rations. The higher weight gain and ADG in pelleted ration are reflected by the increased digestibilities of $\mathrm{OM}, \mathrm{CP}$, and NDF due to the synchronization of available energy with nitrogen. Similarly, Kumari et al. [20] reported higher weight gain and ADG of lambs fed sweet sorghum bagasse based complete rations processed in expander extruded pellet form compared to those fed mashes or chop forms.

Expander-extruder pelleting of mash improved ADG on feeding sugarcane bagasse-based complete ration to calves [42]. Pelletizing the ration increases the simultaneous intake of roughage and concentrate, optimizing the rumen environment, consequently increasing the performance compared to mash, block, and chopped forms. However, the effect of type of processing on weight gain and ADG was not constant throughout the literature, and few researchers reported several inconstancies. For instance, Yasir et al. [44] reported that the lambs fed on oat straw-based complete feed recorded higher ADG in block-fed group than mash fed lambs. Higher ADG was observed in sheep fed mash form of maize stover based complete ration compared to block form [13]. Further, Singh et al. [27] observed similar weight gain and ADG in the calves fed wheat straw-based complete feed in the form of blocks or mash.

Higher nutrient digestibility and efficient utilization of absorbed nutrients in pellet form of ration might have resulted in better feed conversion ratio (FCR) in lambs fed pelleted ration. The beneficial effects of pelletized rations over mash or chopped forms are well evident [38]. The poor feed efficiency of chopped ration might be attributed to lower DMI because of the feed particles' segregation due to differences in bulk density of roughage and concentrate. In contrast to our findings, Karimizadeh et al. [5] showed that feeding the complete feed blocks improved FCR compared with the mash and pellet rations in lambs. Further, Singh et al. [27] observed similar FCR in crossbred calves fed with wheat or rice-based complete ration in either mash or block forms.

\section{Cost economics}

Expander extrusion required additional power consumption for steam production, and hence the cost of processing the pelletized ration increased by $2.92 \%$ over the mash ration. Feeding expander-extruded sorghum stover-based complete ration reduced the cost of feed per unit live weight gain by $11.87 \%, 13.83 \%$, and $9.85 \%$ in comparison to conventional, mash, and block forms, respectively. Despite the higher processing cost, the cost of feed per $\mathrm{kg}$ gain was lower in pelleted ration compared to other rations because of the increased efficiency of nutrient utilization and higher weight gains. In accordance with our results, Kumari [35] observed that feeding expander extruded sweet sorghum bagasse-based complete ration was more economical compared to chop and mash forms in sheep.

Bulk density of feed, defined as ratio of the bulk mass to volume of its fit, plays a crucial role in determining the handling, storage, or transport costs. Because of high fuel and labor prices, high bulk density of feed decreases the cost of handling and transportation [13]. This notion is more pertinent for transporting low-dense rations such as roughages having high bulkiness. The cost of transporting one-ton feed to $100 \mathrm{~km}$ distance through a truck having fuel efficiency of $4 \mathrm{~km} / \mathrm{l}$ was least in block form $(2.70 \$)$, followed by pellet (3.24\$), mash (4.43\$), and chopped $(9.73 \$)$ forms. A major drawback for pellet and block forms of rations is their higher processing costs compared to chopped and mash forms. However, these costs were covered by their higher carrying capacity, lower transportation cost, and better feeding value. Summation of processing and transport cost revealed 
block as a more economical processing form while considering the off-farm expenditure. Although the growth trial revealed higher weight gains in pelletized rations, the overall profit depends on the total distance of the ration to be transported before reaching the farm. In case of farther distances, transporting the block forms would be more advantageous than carrying pelletized rations.

\section{Conclusion}

The study concluded that different physical processing forms (mash, pellet, and block) are more advantageous in terms of nutrient utilization and growth performance of sheep compared to conventional chopped form of sorghum stover-based complete rations. Although the mash, pellet, or block forms have enabled effective utilization of sorghum stover up to $50 \%$ level in complete rations, pelleting the mash with expander extruder procedure was found to be more profitable due to the higher body weight gains, better FCR, and lower feed cost per kg gain. However, the cost economics revealed blocks as more preferable forms for transporting the complete rations to larger distances.

\section{Authors' Contributions}

JN, NNK, TR, and VCP: Designed the study and interpreted the results. JR: Conducted the trial and laboratory analysis. AAK: Supervised the analysis. JR and PRKR: Interpreted the results and drafted the manuscript. All authors read and approved the final manuscript.

\section{Acknowledgments}

This study was funded by CGIAR Research Program on Dryland Cereals, France administrated by APAARI, Thailand. This study was partially supported by the scholarship (ICAR SRF, India) awarded to J. Raju.

\section{Competing Interests} interests.

The authors declare that they have no competing

\section{Publisher's Note}

Veterinary World remains neutral with regard to jurisdictional claims in published and institutional affiliation.

\section{References}

1. Kyryzyuk, S., Krupin, V., Borodina, O. and Adam, W. (2020) Crop residue removal: Assessment of future bioenergy generation potential and agro-environmental limitations based on a case study of Ukraine. Energies, 13(20): 5343.

2. Duncan, A.J., Bachewe, F., Mekonnen, K., Valbuena, D., Rachier, G., Lule, D., Bahta, M. and Erenstein, O. (2016) Crop residue allocation to livestock feed, soil improvement and other uses along a productivity gradient in Eastern Africa. Agric. Ecosyst. Environ., 228: 101-110.

3. Beigh, Y.A., Ganai, A.M. and Ahmad, H.A. (2017) Prospects of complete feed system in ruminant feeding: A review. Vet.
World, 10(4): 424-437.

4. Bhatt, R.S., Soni, L., Sahoo, A. (2019) Methane production and microbial protein synthesis in adult sheep fed total mixed ration as mash and as complete feed block. Carbon Manag., 10(3): 241-253.

5. Karimizadeh, E., Chaji, M. and Mohammadabadi, T. (2017) Effects of physical form of diet on nutrient digestibility, rumen fermentation, rumination, growth performance and protozoa population of finishing lambs. Anim. Nutr., 3(2): 139-144.

6. Safaei, K. and Yang, W. (2017) In: Shields, V.D., editors. Effects of Grain Processing with Focus on Grinding and Steam-Flaking on Dairy Cow Performance, Herbivores. InTech Open, London.

7. Zhang, C., Li, M.M., Al-Marashdeh, O., Gan, L.P., Zhang, C.Y. and Zhang, G.G. (2019) Performance, rumen fermentation, and gastrointestinal microflora of lambs fed pelleted or unpelleted total mixed ration. Anim. Feed Sci. Technol., 253(1): 22-31.

8. Netto, T.T., Massuquetto, A., Krabbe, E.L., Surek, D., Oliveira, S.G. and Maiorka, A. (2019) Effect of conditioning temperature on pellet quality, diet digestibility, and broiler performance. J. Appl. Poult. Res., 28(4): 963-973.

9. Zhu, L., Jones, C., Guo, Q., Lewis, L., Stark, C.R. and Alavi, S. (2016) An evaluation of total starch and starch gelatinization methodologies in pelleted animal feed. $J$. Anim. Sci., 94(4): 1501-1507.

10. Lancheros, J.P., Espinosa, C.D. and Stein, H.H. (2020) Effects of particle size reduction, pelleting, and extrusion on the nutritional value of ingredients and diets fed to pigs: A review. Anim. Feed Sci. Technol., 268(1): 114603.

11. Zhong, R., Zhao, C., Feng, P., Wang, Y., Zhao, X., Luo, D., Cheng, L., Liu, D. and Fang, Y. (2019) Effects of feeding ground versus pelleted total mixed ration on digestion, rumen function and milk production performance of dairy cows. Int. J. Dairy Technol., 73(1): 22-30.

12. Bhuvaneshwari, S., Hettiarachchi, H. and Meegoda, J.N. (2019) Crop residue burning in India: Policy challenges and potential solutions. Int. J. Environ. Res. Public Health, 16(5): 832

13. Anandan, S., Khan, A.A., Ravi, D., Rao, M.S.B., Reddy, Y.R. and Blummel, M. (2013) Identification of a superior dual purpose maize hybrid among widely grown hybrids in South Asia and value addition to its stover through feed supplementation and feed processing. Field Crop Res., 153: 52-57.

14. Lu, X.A. (2020) Meta-analysis of the effects of crop residue return on crop yields and water use efficiency. PLoS One, 15(4): e0231740.

15. Indian Council of Agricultural Research. (2013) Nutrient Requirements of Sheep Goat and Rabbits. Indian Council of Agricultural Research, New Delhi, India.

16. Association of Official Analytical Chemists. (2000) Association of Official Analytical Chemists, Official Methods of Analysis. 16 $6^{\text {th }}$ ed. Association of Official Analytical Chemists, Washington, DC.

17. Van Soest, P.J., Robertson, J.B. and Lewis, B.A. (1991) Methods for dietary fiber, neutral detergent fiber and nonstarch polysaccharides in relation to animal nutrition. $J$. Dairy Sci., 74(10): 3583-3597.

18. Khan, A.A., Sai, M., Rao, B., Ravi, D., Prasad, K.V.S., Anandan, S., Reddy, Y.R. and Blummel, M. (2016) Effect of varying the crop residue, cultivar and physical form on intake and nutrient utilization in Deccani sheep fed complete diets. Anim. Nutr. Feed Technol., 16(2): 197-208.

19. Samanta, A.K., Singh, K.K., Das, M.M., Maity, S.B. and Kundu, S.S. (2003) Effect of complete feed block on nutrient utilization and rumen fermentation in Barbari goats. Small Rumin. Res., 48(2): 95-102.

20. Kumari, N.N., Reddy, Y.R., Blummel, M., Monika, T., Reddy, B.V.S. and Reddy, C.R. (2014) Effect of feeding differently processed sweet sorghum (Sorghum bicolor L. 
Moench) bagasse based complete diet on nutrient utilization and microbial N supply in growing ram lambs. Small Rumin. Res., 117(1): 52-57.

21. Anandan, S., Zoltan, H., Khan, A.A., Ravi, D. and Blummel, M. (2012) Feeding value of sweet sorghum bagasse and leaf residues after juice extraction for bio-ethanol production fed to sheep as complete rations in diverse physical forms. Anim. Feed Sci. Technol., 175(3-4): 131-136.

22. Karangiya, V.K., Savsani, H.H. and Ribadiya, N.K. (2016) Use of densified complete feed blocks as ruminant feed for sustainable livestock production: A review. Agric. Rev., 37: 141-147.

23. Moyo, M. and Nsahlai, I. (2018) Rate of passsage of digesta in ruminants; are goats different? In: Kukovics, S., editor. Goat Science. Intech Open, London. p39-74.

24. Thirumalesh, T., Surekha, K. and Reddy, G.V.N. (2003) Effect of bajra straw based complete diet on nutrient digestibility and rumen metabolism in sheep. Indian J. Anim. Nutr., 20(4): 389-394.

25. Dhuria, R.K., Sharma, T., Purohit, G.R. (2009) Effect of densification of gram straw (Cicer arietinum) based complete feed mixture on performance of Magra lambs. Anim. Nutr. Feed Technol., 9: 231-236.

26. Ebrahimi, S.H. (2020) Feeding complete concentrate pellets containing ground grains or blend of steam-flaked grains and other concentrate ingredients in ruminant nutrition a review. Ann. Anim. Sci., 20(1): 11-28.

27. Singh, P.K., Chandramoni, C., Kumar, K. and Kumar, S. (2016) Effect of feeding wheat and rice straw based complete feed blocks on nutrients utilization, blood biochemical and growth performance in crossbred calves. Indian $J$. Anim. Sci., 86(7): 771-776.

28. Arinola, S.O. and Adesina, K. (2014) Effect of thermal processing on the nutritional, antinutritional, and antioxidant properties of Tetracarpidium conophorum (African walnut). J. Food Process., 2014: 418380.

29. Reddy, G.V.N., Wilhelmina, P.D. and Reddy, M.S. (2003) Effect of differently processed complete diet on performance of Murrah buffaloe. Indian J. Anim. Nutr., 20(2): 131-135.

30. Madhavi, K., Reddy, T.J., Reddy, Y.R. and Reddy, G.V.N. (2009) Effect of feeding differently processed neem seed cake (Azadirachta indica) based complete diet on intake and nutrient utilization in Nellore sheep. Indian J. Anim. Nutr., 26(2): 130-134.

31. Hackmann, T.J. and Firkins, J.L. (2015) Maximizing efficiency of rumen microbial protein production. Front. Microbiol., 6: 465.

32. Reddy, G.V.N., Reddy, M.R. and Reddy, P.B. (1993) Utilization of certain varieties of sorghum straw by sheep. Indian J. Anim. Nutr., 10(3): 173-176.

33. Allen, M.S. (2000) Effects of diet on short-term regulation of feed intake by lactating dairy cattle. J. Dairy Sci., 83(7): 1598-1624.

34. Reddy, G.V.N. and Reddy, M.R. (1991) Effect of processing of cottonseed hulls on nutrient utilization in sheep and goats. Indian J. Anim. Sci., 61(4): 1122-1125.

35. Kumari, N.N. (2011) Effect of Feeding Sweet Sorghum Bagasse (SSB) Based Diets on Nutrient Utilization and Performance in Native Sheep. Ph.D. Thesis submitted to SVVU, Tirupati, India.

36. Reddy, G.V.N., Reddy, K.J. and Nagalakshmi, D. (2001) Nutrient utilization and rumen fermentation pattern of sugarcane bagasse based complete diets in buffalo bulls. Indian J. Anim. Nutr., 18(2): 138-145.

37. Reddy, Y.R., Kumari, N.N., Rao, D.S., Venkateswarlu, M. and Reddy, G.V.N. (2011) Effect of processing fibrous agricultural residue based complete diets on the performance of ruminants. In: Tiwari, S.P. and Sanyal, P.K., editors. Veterinary Nutrition and Health. Satish Serial Publishing House, New Delhi. p485-493.

38. Madhavi, K., Reddy, T.J., Reddy, Y.R. and Reddy, G.V.N. (2006) Effect of feeding differently processed detoxified neem (Azadirachta indica) seed cake based complete diet on growth, nutrient utilization and carcass characteristics in Nellore sheep. Livest. Res. Rural Dev., 18: 140.

39. Reddy, P.R.K., Kumar, D.S., Rao, E.R., Seshiah, V.C., Sateesh, K., Reddy, Y.P. and Hyder, I. (2019a) Assessment of eco-sustainability vis-à-vis zoo-technical attributes of soybean meal (SBM) replacement with varying levels of coated urea in Nellore sheep (Ovis aries). PLoS One, 14(8): e0220252.

40. Reddy, P.R.K., Kumar, D.S., Rao, E.R., Seshiah, V.C., Sateesh, K., Rao, K.A., Reddy, Y.P.K. and Hyder, I. (2019b) Environmental sustainability assessment of tropical dairy buffalo farming vis-a-vis sustainable feed replacement strategy. Sci. Rep., 9: 16745.

41. Reddy, G.V.N., Reddy, K.J. and Nagalakshmi, D. (2001a) Effect of feeding expander extruder processed complete diet containing maize cobs on production performance of buffaloes. Indian J. Anim. Nutr., 18(1): 8-14.

42. Reddy, G.V.N., Reddy, J.K. and Nagalakshmi, D. (2002) Effect of expander extruder processed complete diet containing Sugar cane bagasse on growth and nutrient utilization in Ongole bull calves. Indian J. Anim. Nutr., 72(5): 406-409.

43. Reddy, G.V.N. and Reddy, L.J. (2003) Effect of cotton stalks based complete diets on growth and carcass characteristics in sheep and goats in field conditions. Indian J Anim. Nut, 20(1): 97-100.

44. Yasir, A., Ganai, A.M., Mattoo, F.A. and Shad, F.I. (2009) Comparative dietary evaluation of oats straw and tree leaves based complete feed in block and mash form in sheep. Indian J. Small Rumin., 15(2): 212-216. 